\title{
PRAWOŚĆ I CNOTY POKREWNE. REAKTYWACJA CNÓT ISTOTNYCH W PROCESIE WYCHOWANIA MORALNEGO
}

Streszczenie: Prawość, choć stanowi rdzenną kategorię deontologii i aretologii, relatywnie rzadko staje się przedmiotem badań przedstawicieli pedagogiki. W ramach szerszych badań dotyczących ludzkiej prawości, w niniejszym artykule zaprezentowano ujęcie tej kategorii jako: cnoty (zbiorczej), dyspozycji (bądź cechy) oraz postawy moralnej. Poddano analizie związki prawości z innymi cnotami zbiorczymi (np. godziwością czy szlachetnością), cnotami szczegółowymi (takimi jak sprawiedliwość czy prawdomówność) oraz wartościami moralnymi (zwłaszcza z godnością, prawdą, wolnością). Uzasadniono również konieczność reaktywacji cnót, szczególnie prawości, w procesie wychowania. Odwołując się do aktualnego stanu wiedzy zaakcentowano znaczenie kategorii prawości w rozwoju pedagogiki teoretycznej - subdyscyplin, zwłaszcza teorii wychowania, pedagogiki ogólnej oraz pedeutologii - oraz pedagogiki stosowanej (prezentując wskazówki prakseologiczne dotyczące kształtowania ludzi prawych). Posłużenie się metodami hermeneutycznymi (pól semantycznych oraz interpretacji: wstępnej, zasadniczej, skoordynowanej i kontekstowej) w badaniu problematyki prawości i cnót pokrewnych okazało się uzasadnione, biorąc pod uwagę konieczność pogłębionego ich poznania komparatystycznego.

Słowa kluczowe: prawość; cnota moralna; cnota zbiorcza; postawa moralna; proces wychowania moralnego.

\section{Wprowadzenie}

Przedstawiciele humanistycznej dziedziny nauki - etycy, zwłaszcza deontolodzy i aretolodzy, uznają prawość za cnotę zbiorczą, to znaczy taką, która zawiera liczne cnoty szczegółowe. Cnota zbiorcza nie jest tożsama z żadną cnotą szczegółową, ponieważ obejmuje inne cnoty, stanowiąc w pedagogice odpowiednik ideału wychowania. W myśl takiego stanowiska człowiek prawy uosabia wiele cnót, a zatem wyróżnia się: miłością, dobrocią, sprawiedliwością, prawdomównością, 
praworządnością, dzielnością etyczną, uczciwością itp. Trudno wyczerpać katalog zalet (cnót), które reprezentuje, wartości, które wyznaje, oraz norm bądź zasad, których przestrzega.

Termin „prawość” stanowi tradycyjną kategorię (dziś niesłusznie uznawaną przez niektórych naukowców za anachroniczną). W moim przekonaniu analizowana kategoria ma stałe i niebagatelne znaczenie w wychowaniu moralnym dzieci i młodzieży. Przypomnienie o wysokim statusie kulturowym prawości służy zachęcie do językowego posługiwania się tym terminem nie tylko w dyskursie naukowym, lecz także na co dzień w działalności pedagogów praktyków.

Przy założeniu spójności podmiotu moralnego trzeba było przyjąć konsekwentnie również klasyczne twierdzenie etyczne, reprezentowane już przez Arystotelesa i Platona, że cnoty są ze sobą ściśle powiązane, to znaczy pozostają w łączności, nie zaś w rozłączności (Jaśtal 2015, s. 32). Za przedmiot badań przyjęłam więc powiązania między prawością i wartościami moralnymi oraz cnotami (zbiorczymi i szczegółowymi), a także sposoby wychowawczego reaktywowania zwłaszcza cnoty prawości. Niniejszy tekst stanowi kontynuację wcześniejszych analiz związanych z tą problematyką, a zatem propozycję udzielenia odpowiedzi na kolejne pytania (i zarazem rozwiązanie następujących problemów badawczych):

- $\quad$ z jakimi cnotami ${ }^{10}$ (zbiorczymi i szczegółowymi) oraz wartościami moralnymi jest związana prawość i na czym polegają te powiązania?

- w jaki sposób, dzięki procesowi wychowania moralnego, nauczyciele, wychowawcy i opiekuni mogą kształtować w uczniach, wychowankach bądź podopiecznych takie cechy, cnoty i postawy moralne jak prawość?

Odwołując się do aktualnego stanu wiedzy z zakresu pedagogiki i nauk pokrewnych, w artykule zaakcentuję znaczenie interdyscyplinarnej kategorii prawości oraz terminów zbliżonych semantycznie, takich jak: „godziwość”, „szlachetność” czy „przyzwoitość”, w rozwoju pedagogiki teoretycznej (zwłaszcza jej subdyscyplin: teorii wychowania, pedagogiki ogólnej, pedeutologii), a także pedagogiki stosowanej.

10 Cnota (gr. arete - „to, co najlepsze”, łac. virtus) - cecha osobowa człowieka; czynnik wewnętrzny usprawniający do realizacji dobra moralnego; trwała dyspozycja do właściwego działania; rodzaj sprawności, dzięki której postępuje się należycie pod względem moralnym (sprawność moralna). Początkowo arete oznaczało cechy pożądane ludzi poszczególnych stanów, np. u wojownika ceniono męstwo, zręczność, natomiast pożądanymi cnotami rolnika była wytrwałość, cierpliwość, pracowitość. Przeobrażenia polityczne w starożytnej Grecji spowodowały, że cnoty zaczęly oznaczać cechy dobrego obywatela, aby z czasem stać się ogólnym określeniem cech człowieka żyjącego możliwie jak najlepiej. Tak pojmowana cnota stała się podstawową kategorią etyki starożytnej (zwłaszcza wg Platona, Arystotelesa, św. Tomasza z Akwinu). Oprócz cnót teologalnych: wiary, nadziei i miłości, wylicza się jako cnoty moralne (kardynalne): roztropność, sprawiedliwość, męstwo, umiarkowanie. W czasach nowożytnych pojęcie cnoty przestało odgrywać znaczącą rolę w etyce, a nabrało raczej znaczenia wychowawczego. We współczesnej filozofii moralnej (cnota jako dyspozycja wzorcowa) i teologii moralnej (cnota jako jakość władz duszy) pojęcie cnoty znów nabiera charakteru kluczowego pojęcia etycznego (Maryniarczyk i in. [red.]. 2012, s. 373; Jaśtal 2015, s. 20, 25). 
Oprócz wyjaśnień leksykalnych, poddam analizie powiązania cnoty prawości z innymi cnotami (zbiorczymi i szczegółowymi) oraz wartościami moralnymi.

Celami poznawczymi (inaczej - teoretycznymi) będą więc: (1) zbadanie powiązań między (a) prawością i innymi cnotami zbiorczymi, (b) prawością i wartościami moralnymi i (c) prawością i innymi cnotami szczegółowymi; (2) Wyjaśnienie, na czym polega wychowawcze kształtowanie człowieka prawego.

Z kolei do celów utylitarnych (inaczej - praktycznych) zaliczam:

- $\quad$ promowanie w społeczności odpowiedniego stosunku do prawości oraz cnót pokrewnych;

- zmotywowanie wychowawców, nauczycieli bądź opiekunów do kształtowania w osobowości dzieci i młodzieży wspomnianych dyspozycji wzorcowych, zwłaszcza prawości;

- $\quad$ ukierunkowanie aktywności samowychowawczej dwóch podmiotów: wychowującego i wychowywanego, na wytrwałą oraz kreatywną formację swej prawości.

Posłużenie się w badaniu problematyki prawości i cnót pokrewnych metodami hermeneutycznymi (pól semantycznych oraz interpretacji: wstępnej, zasadniczej, skoordynowanej i kontekstowej) (Grondin 2007; Stępień 2001; Milerski 2011; Tyszczyk, Fiały, Zajączkowski [red.]. 2003) wydaje się uzasadnione, biorąc pod uwagę konieczność ich pogłębionego poznania komparatystycznego.

\section{Prawość i inne cnoty zbiorcze - analiza komparatystyczna. Dociekanie istoty prawości}

Badawcza koncentracja uwagi na relacji między „prawością” i innymi cnotami: "godziwością” (Fundowicz i in. [red.]. 2003), „szlachetnością”, „nieskazitelnością” itp. jest podyktowana powszechnym przekonaniem o ich tożsamości semantycznej, więc także przyzwoleniem na stosowanie zamienne. Twierdzę jednak, że terminy te tylko z pozoru są synonimiczne. W moim przekonaniu, choć są zbliżone, mają odmienny „profil znaczeniowy” oraz charakterystyczne właściwości. Jednak ich wzajemne utożsamianie uniemożliwia wychowawcom dostrzeżenie specyfiki każdego z nich, a także odpowiednie ukierunkowanie procesu wychowania na kształtowanie wspomnianych cech. W naukowej deskrypcji człowieka prawego bardzo pomocne może okazać się wstępne przeanalizowanie przejawów prawości, czyli zasadniczych form manifestowania się tych cech w strukturze charakteru i osobowości człowieka. W tym celu proponuję Czytelnikom sięgnięcie do publikacji, która dostarcza szczegółowego opisu wspomnianych przejawów (Żywczok 2019).

W niniejszym artykule posłużę się terminem „prawy” przede wszystkim odnośnie do: czynu prawego jako spełnienia powinności moralnej; życia prawego polegającego nie tylko na spełnianiu norm etycznych czy religijnych, lecz także na stałym dążeniu do wewnętrznej poprawy; człowieka odznaczającego się licznymi zaletami charakteru, zwłaszcza praworządnego i sprawiedliwego, o którym mówi 
się zazwyczaj, że „idzie drogą prawości”. W określeniu „człowiek prawy” nietrudno odczytać sugestię, iż człowiek ten postępuje zgodnie z prawem, w niczym nie chce prawu uchybić, należy do ludzi sprawiedliwych i dzielnych w upominaniu się o respekt i poszanowanie tych czynników (prawa oraz wartości moralnych i cnót) w życiu zbiorowym.

W dyskursach etyków dotyczących synonimów „człowieka prawego” wylicza się zazwyczaj następujące: „człowiek godziwy”, „człowiek porządny”, „człowiek szlachetny”, „człowiek przyzwoity”, „człowiek poczciwy”, „człowiek cnotliwy”, „człowiek kryształowy”, „człowiek nieskazitelny” (inaczej - „,człowiek bez skazy”) (Cienkowski 1993, s. 195). Terminy te nie są, w moim przekonaniu, tożsame z terminem „człowiek prawy”, choć bez wątpienia należą do zbliżonych semantycznie. W każdym z podanych terminów odzwierciedla się jednak inne nachylenie/wyakcentowanie znaczeniowe, które mogłoby stanowić punkt wyjścia do szczegółowych analiz.

Przeanalizujmy wpierw powiązanie prawości z godziwością - uznawaną za cnotę zbiorczą najbliższą prawości. Posługuję się terminem „godziwy” przede wszystkim odnośnie do: czynu godziwego jako spełnienia powinności moralnej; życia godziwego polegającego na spełnianiu norm etycznych i religijnych, a także na stałym dążeniu do samodoskonalenia; człowieka odznaczającego się licznymi zaletami charakteru i wynikającym z nich dostojeństwem (o takim człowieku mówi się zazwyczaj, że „nie popełnia czynów poniżej godności” bądź „unika niegodziwości").

Staranne porównanie cech człowieka prawego i cech, jakie niegdyś wyliczyła Maria Ossowska, charakteryzując pojęcie godności (Ossowska 1985), pozwala na ukazanie subtelnej różnicy między człowiekiem godziwym (bądź reprezentującym postawę godności) a człowiekiem prawym. Warto jednak zaakcentować, że prawość i godziwość to cnoty zbiorcze, zaś godność (inaczej: człowieczeństwo) - jest wartością, która zdaniem większości etyków (w tym Marii Ossowskiej) - przysługuje każdemu człowiekowi (odmienne stanowisko reprezentuje np. Andrzej Grzegorczyk, który twierdzi, że nie każdy posiada atrybut godności). Fakt ten zdaje się różnicować terminy „godność” i „godziwość”. Chociaż każdy człowiek ma godność (choćby tylko inicjalną, a w toku życia wyzbył się finalnej), nie każdy należy do ludzi godziwych (postępujących godziwie). Godziwość nabywa człowiek postępujący godziwie, co oznacza, że staje się godziwy dzięki czynom godziwym, a nie wskutek wrodzonej godności. Próbując zobrazować usytuowanie analizowanych terminów w płaszczyźnie horyzontalnej, można uznać, że prawość stanowi termin bliższy znaczeniowo godziwości niż godności. W związku z tym (wizualnie - na linii poziomej) godziwość powinna znaleźć się tuż obok prawości. Z kolei, ujmując problem w płaszczyźnie wertykalnej - godność jako wrodzona wartość i (pre)dyspozycja do prowadzenia życia godziwego mogłaby znaleźć się (wizualnie - w linii pionowej) nad godziwością. 
Godziwość (postawa godności) ma znamiona silniej indywidualistyczne niż postawa prawości, gdyż godność osobista i jej naruszenia wiążą się na ogół z tzw. sferą prywatną. Wprawdzie oprócz godności osobistej wyróżnia się także godność społeczną (grupy zawodowej, narodowej), godność rzadziej jednak niż prawość bywa kojarzona z legalnością, czyli praworządnością, a także z aktywnością człowieka w sferze publicznej. Trudno nazwać prawym tego, kto ograniczył swą działalność do „dobroczynności” względem siebie czy jedynie członków swej rodziny. Dowodów prawości dostarcza przecież szersze otoczenie społeczne, które zaświadcza o czynach danego człowieka na rzecz choćby bezinteresownego wspierania określonej społeczności, grupy czy jednostki. Dopiero odpowiednia postawa wobec obcych potwierdza ludzką prawość. Niczym nadzwyczajnym jest uprzywilejowane traktowanie członków rodziny, przyjaciół, ludzi pozostających w relacji koleżeńskiej, bliskich znajomych. Traktowanie obcych jak bliźnich bądź członków rodziny - po bratersku, ujawnia wielkość etyczną człowieka prawego.

Podobnego porównania należałoby dokonać między kolejnymi parami pojęć (cnót zbiorczych): „prawość” i „szlachetność” (względnie między „człowiekiem prawym” i „człowiekiem szlachetnym”), „prawość” i „przyzwoitość” (względnie między „człowiekiem prawym” $i$ „człowiekiem przyzwoitym”), prawość” $i$ „poczciwość” (względnie między „człowiekiem prawym” i „człowiekiem poczciwym”). Należałoby również uwzględnić użycie innych jeszcze terminów zbliżonych semantycznie do prawości i mających swe ugruntowanie w tradycji językowej, np.: „człowiek porządny”, „człowiek cnotliwy”, „człowiek kryształowy”, „człowiek nieskazitelny". Powiązania te zaprezentuję zwięźle, ponieważ na obszerne analizy nie pozwala formuła artykułu. Warto jednak podać tu choć określony kierunek rozumowania.

Termin „człowiek szlachetny” pozwala przypuszczać, iż chodzi o człowieka wielkodusznego i unikalnego pod tym względem, a tym samym niezwykle wartościowego. Z kolei określenie „człowiek przyzwoity” rodzi asocjacje raczej z osobistą sferą funkcjonowania, a także z przestrzeganiem zasad współpracy. Następny termin - „człowiek poczciwy” wiąże się nieodłącznie z przychylnym usposobieniem, przystępnością, skromnością, dobrocią. Biorąc pod uwagę termin „człowiek porządny”, wyraźnie wybrzmiewa słowo „porządek”, co nasuwa skojarzenie $\mathrm{z}$ uporządkowaniem wewnętrznym i zewnętrznym, harmonijnością człowieka. Natomiast w określeniu „człowiek cnotliwy” nietrudno dostrzec akcent położony na uosabianie wielu cnót. W wymowie leksykalnej terminu „człowiek krysztalowy” na pierwszy plan wysuwa się wyraz „kryształ” - nazwa przeźroczystego i bezbarwnego minerału. Regularność i klarowność struktury, jasność i blask kryształu przypomina podobne właściwości wewnętrzne człowieka: przewidywalność postępowania, jasność motywów, blask dobroci i godności, czystość moralną, wręcz nieskazitelność („człowiek nieskazitelny”).

Terminy zbiorcze poddane analizie różnią się więc pod względem semantycznym, choć bez wątpienia daje się między nimi wyodrębnić także podobieństwa, 
zwłaszcza zaś jedno - wyliczone określenia ludzkie należą do zbioru, któremu można by przypisać funkcję gwarancji osiągnięcia „moralnego optimum”.

\section{Powiązania między prawością a wartościami moralnymi i innymi cnotami szczegółowymi}

Literatura filozoficzna, zwłaszcza z zakresu etyki właściwej (Krajewski [red.]. 2009), oraz teologiczna dostarczają argumentów potwierdzających powiązanie prawości (zresztą nie tylko prawości) z kilkoma zasadniczymi wartościami: godnością, miłością, dobrem, wiernością, sprawiedliwością, prawdą i wolnością. Rozpatrzmy wpierw relację między prawością a godnością. Przyjęcie konwencji zadawania zasadniczych pytań i udzielania na nie odpowiedzi zapewni, jak sądzę, pożądaną ścisłość rozumowania oraz pozwoli na ustalenie tożsamości bądź jej braku w przypadku takich pojęć, jak „prawość” i „godność”.

Pytanie: Czy prawość jest, podobnie jak godność, nieredukowalną i niestopniowalną właściwością przysługującą każdemu człowiekowi bez wyjątku, mając na myśli zarówno etap inicjalny ludzkiego życia, jak i finalny? (przywołując definicję "godności" autorstwa Stanisława Jedynaka [red.]. [1999]).

Odpowiedź: Nie, prawość, choć pozostaje niestopniowalna, daje się zredukować i nie stanowi właściwości każdego człowieka $\mathrm{z}$ racji bycia człowiekiem.

Pytanie: Czy prawość jest, podobnie jak godność, równoznaczna z podmiotowością człowieka i jego uprzywilejowanym miejscem w przyrodzie? (według ujęcia godności autorstwa Wojciecha Chudego [2005]).

Odpowiedź: Nie, prawość nie jest prostym odpowiednikiem podmiotowości człowieka, choć trudno zaprzeczyć, że ową podmiotowość współtworzy, potwierdzając wyjątkowe miejsce człowieka wśród innych stworzeń.

Pytanie: Czy prawość jest, podobnie jak godność, trwałym przekonaniem jednostki o jej autentycznej wartości jako człowieka, inaczej - poczuciem własnej wartości? (w myśl stanowiska Józefa Kozieleckiego [1977]).

Odpowiedź: Nie, prawości nie daje się sprowadzić jedynie do poczucia własnej wartości, choć z pewnością w pewnej mierze z niego wynika.

Pytanie: Czy prawość, podobnie jak godność, stanowi synonim człowieczeństwa?

Odpowiedź: Tak, jeśli człowieczeństwo pojmuje się jako osiągnięcie bardzo wysokiego poziomu rozwoju moralnego - tzw. dojrzałości moralnej.

Pytanie: Czy prawość, podobnie jak godność, oznacza postępowanie zgodne $\mathrm{z}$ nakazami sumienia?

Odpowiedź: Tak, jeśli weźmiemy pod uwagę jedynie nakazy tzw. „czystego sumienia” bądź „wrażliwego sumienia”, podpowiadającego trafnie, jakich dokonywać wyborów i jak należy żyć.

Wyodrębnienie różnic i podobieństw między pojęciami „prawości” i „godności" umożliwiło wykazanie ich nierównoznaczności, choć jednak pewnej bliskości semantycznej. 
Na uwagę zasługuje z kolei powiązanie prawości z miłością, dobrem i wiernością. W Biblii Chrystus (jako Syn Boga i człowiek prawy) nie bez powodu został okrzyknięty „miłującym praworządność” (Podstawka 2016, s. 886), uprawnione jest zatem uznanie prawości za odmianę miłości. „Miłość praworządności”, stanowiąc połączenie cnoty kardynalnej - miłości z przestrzeganiem prawa, ukazuje kwintesencję prawości. Człowieka naśladującego prawość Chrystusa cechuje więc umiłowanie ładu społecznego wynikającego zarówno z przestrzegania prawa, jak i realizowania wartości moralnych oraz duchowych. Ludzi prawych wyróżnia także wierność objawiającemu się im osobowemu Bogu i Jego prawu. Związek trzech wartości moralnych: miłości, dobra i wierności, a zwłaszcza współzależność ludzkiej postawy miłości, dobra oraz wierności wydaje się oczywiste, choć niełatwe do realizacji. W człowieku prawym manifestuje się jednak wzorowo koegzystencja miłości, dobroci, a także wierności.

W wyjaśnieniu kolejnej kwestii - łączności prawości ze sprawiedliwością skorzystam z dziedzictwa Arystotelesa. Filozof pisze: „prawość [...] sama jest czymś sprawiedliwym i [...] czymś lepszym od sprawiedliwości [...]. A więc sprawiedliwość i prawość są tym samym i choć obie są szlachetne, to jednak prawość stoi wyżej. Wątpliwość zaś rodzi się stąd, że to, co prawe, jest wprawdzie sprawiedliwe, jednakże nie w znaczeniu sprawiedliwości stanowionej, gdyż jest korekturą sprawiedliwości stanowionej" (Arystoteles 2007, s. 189). Arystoteles, twierdząc, że „prawość stoi wyżej od sprawiedliwości”, ma na myśli prawdopodobnie szerszy zakres pojęcia prawości w stosunku do pojęcia sprawiedliwości, i w związku z tym podkreśla nadrzędne usytuowanie prawości. W każdym postępowaniu prawym daje się dostrzec zarys sprawiedliwości, lecz czyny sprawiedliwe tylko częściowo konsty tuują postawę prawości, choć dzięki niej mogą zostać zainicjowane. Prawość staje się - w myśl stanowiska Arystotelesa - warunkiem koniecznym do zaistnienia sprawiedliwości, jednak sprawiedliwość, choć współtworzy postawę prawości, okazuje się niewystarczająca do ukształtowania człowieka prawego. Dopiero wtedy, gdy prawość staje się przyczyną (a także celem i środkiem czynów czy działania), można mówić o realizacji sprawiedliwości. Prawość jest więc podstawą szacunku wobec praw przysługujących każdemu człowiekowi (Wyszyński 1993) oraz podłożem szacunku względem sprawiedliwości jako wartości.

Analiza przejawów ludzkiej prawości pozwala dostrzec jej koincydencję również z prawdą, a zatem także związek z normą moralną nakazu: „mów prawdę”. Prawdomówność świadczy o prawości i uwydatnia prawość człowieka, który nie zniża się do kłamstwa, zatajania prawdy czy manipulacji zniekształcających prawdę $\mathrm{w}$ kwestiach uznawanych powszechnie za istotne. Człowiek prawy nie wymieni szczerości na doraźne korzyści wynikające z odmowy powiedzenia bądź wyznania prawdy.

W ontologiczno-teologicznej koncepcji moralności autorstwa św. Anzelma z Cantenbury, zawartej w dziele De veritate, pojęciem kluczowym jest m.in. prawość, a przedmiotem dociekan - zależność między prawością a prawdą. Prawość 
oznacza tu, że coś jest prawdziwe (istniejące zgodnie z Bożym zamiarem). Prawość, podobnie jak prawda, należy do wartości absolutnych, których status nie wymaga dodatkowych uzasadnień czy motywacji zewnętrznej. Prawość pozostaje również bezpośrednio dostępna ludzkiemu poznaniu i praktykowaniu jej jako wdrożeń prawdy (Karaś 2013).

Kolejny typ analizowanych powiązań dotyczy relacji między prawością i wolnością. Rozważeniu jej św. Anzelm poświęcił swe dzieło De libertate arbitri. Specyficznym zespoleniem prawości i wolności staje się, w jego przekonaniu, „prawość woli”, to znaczy poprawny akt woli. Prawość pełni wobec wolnej woli funkcję kontrolną (a raczej - funkcję samokontroli), polegającą na obserwacji jej poczynań, i funkcję prewencyjną (Karaś 2013), zapobiegając uleganiu niepożądanym motywom i wpływom. Wolność jako wartość odosobniona traci swe znaczenie deontyczne, zaś działanie ludzkie, wprawdzie podjęte z wolnej woli, lecz pozbawione specyfiki prawości, wydaje się zubożone, a wręcz pozbawione sensu.

Oprócz wyżej przeanalizowanych powiązań między prawością i innymi wartościami: miłością, dobrem, wiernością, sprawiedliwością, prawdą, wolnością dałoby się z pewnością wyliczyć związki prawości z wieloma jakościami aretologicznymi. Trudno bowiem nie przyznać słuszności twierdzącym, że można zauważyć łączność prawości również z cnotą roztropności (por. Jan Paweł II 1982), dzielności etycznej (Zabielski 2015; Bocheński 1999), odpowiedzialności, otwartości itd.

Reasumując, za pośrednictwem hermeneutycznej analizy tekstów źródłowych można rozpoznać i potwierdzić powiązanie prawości z kilkoma zasadniczymi wartościami: godnością, miłością, dobrem, sprawiedliwością, prawdą i wolnością. Wśród cnót szczegółowych wyraźną zaś łączność z prawością wykazują zwłaszcza: dobroć, sprawiedliwość, prawdomówność, roztropność, dzielność etyczna, odpowiedzialność, a także otwartość.

\section{Wychowanie do uosabiania prawości, czyli bycia prawym - trwała lokata człowieczeństwa}

Cenny w pedeutologii wydaje się namysł nad nauczycielską osobowością i charakterem, w co wpisana jest m.in. taka cecha, jak prawość. Oto reprezentatywne fragmenty dostarczające opisu prawości wychowawcy: „Prawy wychowawca to człowiek, który w sposób wolny szczerze szuka prawdy, daje jej świadectwo w swym postępowaniu, kieruje się [...] dobrem moralnym własnym oraz wychowanków [...]. Podstawą prawości nauczyciela jest prawda i dobro moralne jako fundament etycznego odnoszenia się do wychowanka i samego siebie. Prawość nauczyciela wyraża się w uwzględnieniu praw etycznych i powinności moralnych w procesie wychowawczym” (Podstawka 2016, s. 889) oraz w „[...] ukazywaniu wartości prowadzącym do wolnego i świadomego włączenia ich w [...] indywidualny system wartości wychowanków, konstruujący ich [...] osobową tożsamość moralną" (Podstawka 2016, s. 889). „[...] prawość [...] nauczyciela rodzi w nim zrozumienie 
godności i szlachetności tego, co istnieje, a także skromność oraz uznanie praw i żądań wszelkich form życia. Prawy nauczyciel jest pozbawiony nadmiernego egoizmu [...], pychy i pożądliwości. Daje możliwość rozwoju swym wychowankom otaczając ich życzliwością i pomocą" (Leszkowicz-Baczyński 1995, s. 90). W przytoczonych fragmentach, jak można stwierdzić, znamienne dla prawości wychowawczej jest: respektowanie powinności moralnych (własnych i wychowanków), skromność i wynikająca z niej wyrozumiałość, a także życzliwość (względnie przychylność) oraz uczynność (ewoluująca w kierunku postaw altruistycznych). Prawość stanowi więc doskonały „budulec” autorytetu deontycznego i epistemicznego nauczyciela bądź wychowawcy.

Przekonanie odbiorców kultury (w tym nauczycieli, wychowawców i opiekunów młodego pokolenia), że warto praktykować cechę taką jak prawość oraz postawę prawości w codzienności edukacyjnej, kładzie już podwalinę pod pozytywne działania oraz sukcesywną przebudowę realiów społecznych. W tworzenie optymalnych warunków wychowawczych wpisana jest konieczność aranżowania odpowiednich sytuacji w danym środowisku. Nie zawsze uzasadnione jest projektowanie określonych sytuacji wychowawczych (np. przeprowadzenie zajęć z zakresu edukacji aksjologicznej przy uwzględnieniu analizy pojęcia prawości). Niekiedy pożądane sytuacje nadarzają się spontanicznie, stanowiąc cenne ukierunkowanie postępowania wychowanka. Do sytuacji tego typu należą choćby zdarzenia z życia szkolnego wymagające obrony (np. przeciwstawienie się mobbingowi) kolegi/ koleżanki z klasy, bezinteresowna, systematyczna pomoc koleżeńska w nauce (np. w przygotowaniu do egzaminów), udzielenie wsparcia psychicznego koledze/ koleżance w sytuacji przewlekłej choroby (bądź choroby rodzica, rodzeństwa), a także po stracie kogoś bliskiego (rodzica, rodzeństwa, dziadków), zapewnienie wsparcia finansowego rodzinie kolegi/koleżanki z klasy dzięki wspólnemu zorganizowaniu przez uczniów i nauczycieli festynu, koncertu, projekcji filmów, które można dobrać problemowo (np. na temat: „Człowiek prawy - potrzebny od zaraz”; „Oblicza prawości”; „Nieprawość - i co dalej?”), wystawienia sztuki teatralnej, przygotowania galerii prac plastycznych (plakatów, obrazów, rysunków, szkiców tematycznych) lub ekspozycji wytworów literackich. Prawość młodzieży kształtują również zachodzące w otoczeniu skomplikowane sytuacje konfliktowe, które ta optymalnie, pod względem etycznym i moralnym, rozwiązuje. Jedne z nich wymagają umiejętności przyjęcia rozwiązania kompromisowego („pójścia na kompromis”), a inne - bezkompromisowości.

Pozytywna atmosfera wychowania może generować sytuacje, w których uczeń, wychowanek bądź podopieczny będzie mógł wykazać się swą prawością, jednak prawdopodobnie częściej ciąg sprzyjających sytuacji przyczynia się do wzmocnienia właściwej atmosfery. Klimatu wychowawczego procentującego rozwojem takiej dyspozycji, jak prawość nie uda się opisać w kilku zdaniach. Warto jednak zaakcentować, że konstytuują go podstawowe właściwości ludzi prawych - wrażliwość i dojrzałość aksjologiczna, które predysponują do przejawiania wielu cnót. 
Sporo zależy od tego, czy nauczyciel, wychowawca, opiekun jest człowiekiem prawym. Jeśli tak, zadba on o to, aby liderami grupy klasowej bądź innej został właśnie uczeń, wychowanek, podopieczny, który jest prawy (zwłaszcza w warunkach chaosu etycznego i prób uprzywilejowania rażących przejawów nieprawości). Refleksje w tym zakresie, to znaczy studia nad sytuacją i atmosferą wychowania, mogą okazać się pomocne dla pedagogów stosujących na co dzień praktyczne dyrektywy pedagogiki.

Do metod wychowania, jakie wydają się najbardziej sprzyjające w kształtowaniu w wychowankach takiej dyspozycji, jak prawość, z pewnością należą:

- metoda modelowania (polegająca na wzorowaniu się na ludziach prawych oraz identyfikacji z nimi, a także wyznaczaniu prawości jako celu wychowania i samowychowania);

- metoda nadawania znaczenia (określonym zdarzeniom, faktom, związanym zarówno z zaobserwowanymi przejawami prawości, jak i nieprawości), służąca właściwej ich interpretacji oraz wartościowaniu;

- metoda treningu (dyspozycji, za pośrednictwem wykonywania bądź powtarzania określonych czynności i działań składających się na postępowanie prawe).

Warto dodać, że mniejsze znaczenie w wychowaniu człowieka prawego będzie miała metoda presji sytuacyjnej (inaczej - prowokacji), gdyż zbyt silnie ingeruje ona w sferę emocjonalną, indywidualne wybory moralne i decyzje wychowanka oraz nie uwzględnia w dostatecznym stopniu takich czynników, jak: samostanowienie, tendencje samowychowawcze, autokreacyjne czy autokorektywne.

Analizując z kolei różne formy wychowania, które są optymalne w kształtowaniu człowieka prawego, okazuje się, że organizacja zajęć (lub spotkań) zarówno w formie indywidualnej, jak i zespołowej czy zbiorowej może należeć do działań konstruktywnych pod względem formacji aksjologicznej i aretologicznej. Oprócz zastosowania przez nauczyciela, wychowawcę bądź opiekuna właściwych metod czy form, przy kształtowaniu określonej dyspozycji (w tym wypadku prawości) warto respektować zasady wychowania, zwłaszcza takie, jak: zasada indywidualizacji (skłaniająca wychowawcę do uprzystępnienia treści przekazywanych wychowankom); aktywności (włączenia wychowanka w realizację celu samorozwoju); motywacji (zwłaszcza samowychowawczej); trwałości (utrwalania efektów procesu wychowania); systemowości (inaczej - integralności, to znaczy harmonijnego zaangażowania wszystkich sfer rozwoju wychowanka: poznawczej, emocjonalno-uczuciowej, wolicjonalnej, moralnej, duchowej). Stosując te zasady, należy jednocześnie umacniać więź emocjonalną z wychowankami przez serdeczny kontakt, okazywać im szczerą wyrozumiałość oraz szacunek.

Jako egzemplifikację prakseologicznego zastosowania propozycji wychowania do prawości niech posłuży czytelnictwo biografii ludzi uznanych powszechnie za prawych. Warto skorzystać z opublikowanych biografii współczesnych 
błogosławionych ${ }^{11} \mathrm{i}$ świętych oraz innych prawych ludzi ${ }^{12}$, gdyż obfitują one we wzorce postępowania pomocne w ukierunkowaniu decyzji czy postępowania młodzieży wyłącznie na cele wartościowe. Ukazane w biografiach losy ludzkie i przykładne metody pokonywania przez nich trudności życiowych wzbudzają szacunek i wdzięczność wobec poprzedników, rodzą pozytywne uczucia sympatii i podziwu, a także przekonują do dochowania wierności wartościom moralnym oraz pozytywnym, głębokim i trwałym więziom emocjonalnym. Należy podkreślić, że praca nauczyciela, wychowawcy bądź opiekuna z dziećmi lub młodzieżą w zaprezentowany powyżej sposób będzie nie tylko oddziaływać konstruktywnie na wychowanków, lecz będzie motywować również wychowawców do samorozwoju. Istnieją podstawy, aby przewidywać, że ich zaangażowanie w wychowanie moralne dzieci i młodzieży okaże się znaczące także dla nich samych - autoedukacji oraz rozwoju duchowego nauczycieli.

Odniesienie prawości i cnót pokrewnych do wielu:

- podmiotów wychowujących (np.: rodziców, wychowawców, pedagogów, opiekunów, nauczycieli, animatorów, pracowników socjalnych, asystentów rodzin, kuratorów sądowych);

- podmiotów wychowywanych (np.: potomstwa, uczniów, wychowanków, podopiecznych);

- środowisk wychowujących (m.in. do środowiska rówieśniczego);

- placówek i instytucji: wychowawczych, kulturalnych, opiekuńczych i socjalnych.

Z pewnością uzupełniłoby stan wiedzy pedagogicznej w tym zakresie. Nie wydaje się możliwe uczynienie tego w ramach tej jednej publikacji, można natomiast przewidywać, że niniejszy artykuł przyczyni się do powstania kolejnych tekstów, nie pozostawiając problematyki zainteresowaniu jedynie naukowców prawników (na co wskazywałyby terminy „prawość”, „prawy”) czy etyków, do których z racji ich profesji należy zgłębianie zagadnienia prawości.

\section{Podsumowanie}

Uogólnienie wyników niniejszych analiz i refleksji prowadzi do wysunięcia następujących wniosków:

1. Choć uważa się na ogół, że „człowiek godziwy”, „człowiek szlachetny”, „,złowiek przyzwoity”, „człowiek poczciwy”, „człowiek porządny”, „człowiek

11 Jako wzory osobowe mogą posłużyć biografie bł. ks. Jerzego Popiełuszko (zob.: Wójtowicz 2010; Czaczkowska, Wiścicki 2009) oraz kardynała Stefana Wyszyńskiego (Wyszyński 1982; Czarcińska, Gałka [red.]. 2018), którego beatyfikacja ma nastąpić w najbliższym czasie.

12 Za interesującą propozycję biograficzną może posłużyć sylwetka Klimka Bachledy, który z niezwykłym poświęceniem ratował ludzi. W czasie akcji ratowniczej zginął w górach, które tak ukochał (Stróżewski 2002, s. 42). 
cnotliwy”, „człowiek kryształowy”, „człowiek nieskazitelny” to synonimy „człowieka prawego”, twierdzę, iż pojęcia te nie są tożsame. W tym celu wykazałam powiązania między prawością i innymi cnotami zbiorczymi, zwłaszcza między prawością i godziwością. Poddałam analizie również wymowę semantyczną pozostałych terminów.

2. Literatura filozoficzna oraz teologiczna dostarczają argumentów potwierdzających powiązanie prawości z kilkoma zasadniczymi wartościami: godnością, miłością, dobrem, wiernością, sprawiedliwością, prawdą i wolnością. Daje się dostrzec również inny kierunek w ujmowaniu prawości, mianowicie potraktowanie jej jako cnoty zbiorczej, którą współtworzą cnoty szczegółowe, takie jak: sprawiedliwość, dobroć, prawdomówność, dzielność, uczciwość, roztropność, odpowiedzialność.

3. Oprócz etycznego ujęcia prawości, rozumianej m.in. jako cnota, dyspozycja (wzorcowa), norma postępowania i powinność moralna, w pedagogice, zwłaszcza w jej subdyscyplinach - teorii wychowania, pedagogice ogólnej (Stępkowski 2010) oraz pedeutologii, najistotniejsze okazuje się postrzeganie prawości jako cechy charakteru, postawy moralnej, celu wychowania, komponentu ideału wychowania, budulca autorytetu pedagogicznego, składnika wzoru osobowego i wzorca postępowania.

4. Uosabianie prawości, czyli bycie prawym, stanowi wyróżnik dobrego nauczyciela, wychowawcy bądź opiekuna dzieci i młodzieży. Natomiast interioryzacja w młodym pokoleniu takiej wartości, jak prawość zachodzi za pośrednictwem odpowiedniego procesu wychowania, zaś przejawia się w cechach, a także w postawie uczniów, wychowanków i podopiecznych. Postawę prawości można uznać także za naturalne przeciwdziałanie eskalacji nieprawości.

5. Stan rozwoju prakseologicznego współczesnej pedagogiki umożliwia nauczycielom, wychowawcom i opiekunom korzystanie z wielu metod, form, zasad, środków, treści edukacji aksjologicznej (w tym dotyczących wychowania moralnego), aranżowania odpowiednich sytuacji wychowawczych oraz tworzenia właściwej atmosfery wychowania w celu ukształtowania ludzi prawych. Wiele zależy od tego, czy nauczyciele potrafią umiejętnie korzystać (angażując uczniów) również z nadarzających się w środowisku wychowawczym okoliczności, które wymagają udzielenia komuś pomocy, wsparcia, okazania troski, ujawnienia emocji i uczuć pozytywnych. Doskonale kształtują prawość młodego człowieka również konstruktywnie rozwiązane przez niego sytuacje konfliktowe. Posłużenie się przez nauczyciela bądź wychowawcę właściwymi metodami wychowania: modelowania, treningu, nadawania znaczenia, a także formami organizacyjnymi: indywidualną, zespołową i zbiorową, pozwolą na tworzenie dogodnych warunków wychowawczych, potrzebnych do ukształtowania ludzi prawych. Realizacji tego celu sprzyja również nauczycielskie respektowanie zasad wychowania, 
zwłaszcza takich, jak zasady indywidualizacji, aktywności, motywacji, trwałości, systemowości. Przekazanie w trakcie zajęć z dziećmi i młodzieżą informacji biograficznej lub autobiograficznej o ludziach prawych (stanowiących wzór osobowy) czy przygotowanie wytworów artystycznych na temat prawości - to tylko nieliczne propozycje z szerokiej oferty zajęć, które mogłyby pobudzić uczniów bądź wychowanków do twórczej i zarazem wartościowej pracy w szkole (na każdej lekcji, tym bardziej więc na lekcji wychowawczej czy religii), na zajęciach pozalekcyjnych (np. w ramach kół zainteresowań oraz szkolnego klubu sportowego) bądź pozaszkolnych (np. $\mathrm{w}$ domach kultury, klubach integracji środowiskowej, miejskich ośrodkach pomocy rodzinie, stowarzyszeniach i ruchach katolickich, parafialnych centrach młodzieży).

\section{Bibliografia}

Arystoteles (2007). Etyka nikomachejska. Gromska D. (tłum.). Warszawa: Wydawnictwo Naukowe PWN.

Bocheński J. M. (1999). Patriotyzm, męstwo, prawość żołnierska. WarszawaKomorów: Fundacja Pomocy „Antyk”, Wydawnictwo Antyk Marcin Dybowski. Chudy W. (2005). Godność człowieka wartościa ontyczno-wychowawczą. W: Kalinowski M. (red.). Wzrastanie w godności, miłości i miłosierdziu. KrakówLublin: Wydawnictwo Katolickiego Uniwersytetu Lubelskiego, s. 76-85.

Cienkowski W. (1993). Praktyczny słownik terminów bliskoznacznych. Warszawa: Polska Oficyna BGW.

Czaczkowska E. K., Wiścicki T. (2009). Ksiądz Jerzy Popiełuszko. Warszawa: „Świat Książki”.

Czarcińska I., Gałka A. (red.). (2018). Stefan Wyszyński. Pro memoria, t. 3: 19531956. Warszawa: Instytut Pamięci Narodowej, Uniwersytet Kardynała Stefana Wyszyńskiego.

Fundowicz S., Rymarz F., Gomułowicz A. (red.). (2003). Prawość i godność: księga pamiatkowa w 70. rocznice urodzin profesora Wojciecha Łączkowskiego. Lublin: Wydawnictwo Katolickiego Uniwersytetu Lubelskiego.

Grondin J. (2007). Wprowadzenie do hermeneutyki filozoficznej. Łysień L. (tłum.). Kraków: Wydawnictwo WAM.

Jan Paweł II (1982). Cnota roztropności. Przemówienie na audiencji ogólnej, 25 X 1978. W: Jan Paweł II. Nauczanie społeczne 1978-1979, t. 2, wybór Różycka B., Nitecki P. Warszawa: Wydawnictwo Ośrodka Dokumentacji i Studiów Społecznych, s. 28-30.

Jaśtal J. (2015). Etyka i czas. Wariacje aretologiczne. Kraków: „Księgarnia Akademicka".

Jedynak S. (red.). (1999). Mały słownik etyczny. Bydgoszcz: Wydawnictwo Branta. 
Karaś A. (2013). Św. Anzelma z Cantenbury ontologiczno-teologiczny system moralności. „Studia Redemptorysowskie”, 11, s. 69-80.

Kozielecki J. (1977). O godności człowieka. Warszawa: Wydawnictwo „Czytelnik”. Krajewski K. (red.). (2009). Racjonalnossć w etyce. Sumienie, prawość i twórczość. Lublin: Wydawnictwo Katolickiego Uniwersytetu Lubelskiego.

Leszkowicz-Baczyński J. (1995). Charakterystyka wyborów niektórych wartości akceptowanych przez młodych nauczycieli (komunikat z badań). W: Kaszyński K., Żuk-Łapińska L. (red.). Etyka zawodu nauczyciela. Nauczanie etyki. Zielona Góra: Wyższa Szkoła Pedagogiczna, s. 78-92.

Maryniarczyk A., Jaroszyński P., Kiereś H., Zdybicka Z. J. (red.). (2012). Słownik przewodnik filozoficzny. Osoby-problemy-terminy. Lublin: Polskie Towarzystwo Tomasza z Akwinu.

Milerski B. (2011). Hermeneutyka pedagogiczna. Perspektywy pedagogiki religii. Warszawa: Wydawnictwo Naukowe ChAT.

Ossowska M. (1985). Normy moralne, próba systematyzacji. Warszawa: Państwowe Wydawnictwo Naukowe.

Podstawka K. (2016). Prawość. W: Chałas K., Maj A. (red.). Encyklopedia aksjologii pedagogicznej. Radom: Polskie Wydawnictwo Encyklopedyczne „Polwen”, s. $885-889$.

Stępień A.B. (2001). Wstęp do filozofii. Lublin: Towarzystwo Naukowe Katolickiego Uniwersytetu Lubelskiego.

Stępkowski D. (2010). Pedagogika ogólna i religia. (Re)konstrukcja zapomnianego wątku na podstawie teorii Johanna F. Herbarta i Friedricha D. E. Schleiermachera. Warszawa: Towarzystwo Naukowe Franciszka Salezego.

Stróżewski W. (2002). O wielkości. Szkice z filozofii człowieka. Kraków: Wydawnictwo „Znak”.

Tyszczyk A., Fiały E., Zajączkowski R. (red.). (2003). Wartość i sens. Aksjologiczne aspekty teorii interpretacji. Lublin: Wydawnictwo Katolickiego Uniwersytetu Lubelskiego.

Wójtowicz M. (2010). Błogosławiony Jerzy - dojrzewanie do świętości. Warszawa: Wydawnictwo Sióstr Loretanek.

Wyszyński S. (1982). Zapiski więzienne. Paris: Dialogue/Znaki Czasu.

Wyszyński S. (1993). Miłość i sprawiedliwość społeczna. Rozważania społeczne. Poznań: Pallottinum.

Zabielski J. (2015). Roztropność, męstwo, umiarkowanie i sprawiedliwość jako wyznaczniki chrześcijańskiej moralności. Studium tomistyczno-aksjologiczne. Warszawa: Wydawnictwo Naukowe Uniwersytetu Kardynała Stefana Wyszyńskiego.

Żywczok A. (2019). Prawość - zapomniana cnota. Głos w kwestii reprodukcji prawości w strukturze charakteru i osobowości młodego pokolenia. „Roczniki Pedagogiczne", 4, s. 5-18. 


\title{
RECTITUDE AND THE RELATED VIRTUES. REVIVAL OF ESSENTIAL VIRTUES IN THE PROCESS OF MORAL EDUCATION
}

\begin{abstract}
Rectitude, being a crucial category of deontology and arethology, is relatively rarely studied by representatives of sciences, such as pedagogy. The author approaches selected issues within a wider scope of research concerning human rectitude. This paper aims to answer the following questions: what kind of moral values and what particular virtues rectitude is associated with, and how, through a process of moral education can teachers, educators and care-takers shape in their students or subordinates such traits (and moral attitudes) as rectitude? Referring to the current state of knowledge the author emphasizes the significance of interdisciplinary category of rectitude in the pedagogical thinking, and presents both traits in the scientific context of collective virtue, disposition (trait) and moral attitude. The author also analyses the relationships between rectitude and other moral values or virtues. The hermeneutical methods applied in this research proved especially useful in view of the comparative character of the study.
\end{abstract}

Keywords: rectitude; moral virtue; collective virtue; moral attitude; process of moral education.

Alicja Żywczok - doktor habilitowana, prof. UŚ, pedagog i filozof. Pracuje w Instytucie Pedagogiki Wydziału Nauk Społecznych Uniwersytetu Śląskiego w Katowicach. Jej zainteresowania badawcze to: teoria wychowania, naukoznawstwo ogólne, antropologia filozoficzna, etyka pedagogiczna. Członkini Zespołu Teorii Wychowania i Pedagogiki Ogólnej przy KNP Polskiej Akademii Nauk. Autorka ponad 1oo publikacji naukowych. Najważniejsze prace monograficzne: Filozoficzne korzenie pedagogiki radości (2000); Wychowanie do radości życia (2004); Aksjologia odkrycia naukowego - studium rozwoju i wychowania osobowości naukowych (2009); Ku afirmacji życia. Pedagogiczne podstawy pomyślnej egzystencji (2011); Wychować człowieka prawdomównego. Koncepcje, badania naukowe, wdrożenia (2016); Miłość - akt preferencji duchowości człowieka. Studium bliskości uczuciowej ([red.], 2013); Znajomość, koleżeństwo, przyjaźń. Dynamizm ewoluowania więzi emocjonalnej ([red.], 2014); Kierunki rozwoju etyki pedagogicznej i teorii wychowania moralnego ([red.] części monograficznej «Chowanny» 2016, t. 1: Naukowcy. Osobowość, rola, profesjonalizm ([współred.], 2019). Adres korespondencyjny: 40-126 Katowice, ul. Michała Grażyńskiego 53. Adres e-mailowy: alicjazyw@wp.pl. 